\title{
IMPLEMENTASI KEBIJAKAN KELAS OLAHRAGA DI SMP NEGERI KOTA BENGKULU
}

\author{
Liza Oktavina \\ Penjas fkip unib, e-mail:oktafinaliza@gmail.com \\ Tono Sugihartono \\ Universitas Bengkulu
}

Ari Sutisyana

Universitas Bengkulu

\begin{abstract}
Abstrak
Penelitian ini bertujuan untuk mendeskripsikan tentang implementasi kebijakan kelas olahraga di SMP Negeri Kota Bengkulu. Permasalahan yang dikaji dalam penelitian ini adalah Bagaimanakah Implementasi Kebijakan Kelas Olahraga di SMP Negeri Kota Bengkulu. Jenis penelitian deskriptif analitik. Subjek Penelitian ini adalah kepala sekolah, pengurus, pelatih dan siswa kelas olahraga SMP Negeri 2, SMP Negeri 18 dan SMP Negeri 16 Kota Bengkulu. Teknik pengumpulan data menggunakan observasi, wawancara, dan dokumentasi. Analisis data dengan mereduksi data, penyajian data dan penarikan kesimpulan. Hasil penelitian dan pembahasan menunjukkan bahwa kebijakan kelas olahraga dimandatkan oleh Kemendikbud RI, implementasi kebijakan kelas olahraga belum sepenuhnya sesuai dengan panduan pelaksanaan kelas olahraga dapat dilihat dari belum adanya fasilitas khusus untuk kelas olahraga, minimnya dana, ketidakteraturan jadwal latihan kondisi fisik, kurangnya pengawasan dari pemerintah, sehingga bisa menghambat tercapainya tujuan kelas olahraga di SMP Kota Bengkulu. Kesimpulan dari penelitian ini menunjukkan bahwa implementasi kebijakan kelas olahraga di SMP Kota Bengkulu belum berjalan sebagaimana mestinya.
\end{abstract}

Kata Kunci: Implementasi, Kebijakan Kelas Olahraga, SMP

\begin{abstract}
This research aimed to describe about the implementation of sport class policy in SMP Bengkulu city The problem reviewed in this research was "How is the implementation of Sport Class Policy in SMP Negeri Kota Bengkulu?" This research was an analytical descriptive design. The subject of this research was headmaster, administrator, trainer and students in sport class of SMP Negeri 2, SMP Negeri 18 and SMP Negeri 16 Bengkulu city. collection technique used in this research was observation, interview, and documentation methods. file analysis used in this research was by reduction, resentation and taking conclusion. The result and discussion showed that sport class policy was mandated by Kemendikbud RI. The implementation of sport class policy was not fully appropriate with the guidance of implementing sport class that can be seen from special facilities for sport class was not yet exist, lack of funds, irregularity of physical condition training schedule, and lack of government control, so it can inhibit the goals achievement of sport class in SMP Bengkulu
\end{abstract}


KINESTETIK : Jurnal IImiah Pendidikan Jasmani,2 (1) 2018.

city. The conclusion of this research showed that the implementation of sport class policy in SMP Bengkulu city was not yet running as it should be.

Keywords: Implementation, Sport class policy, SMP

\section{PENDAHULUAN}

Pendidikan merupakan suatu kegiatan yang secara sadar dan disengaja serta penuh tanggung jawab yang dilakukan oleh orang dewasa kepada anak. Pemerintah sebagai pengelola pendidikan berupaya keras dalam meningkatkan program-program peningkatan kualitas pendidikan. Sumbangsih pendidikan dalam mendukung upaya peningkatkan prestasi olahraga Nasional melalui Direktorat Jendral Manajemen Pendidikan Dasar dan Menengah, Kementerian Pendidikan Nasional menyelenggarakan program kelas olahraga pada jenjang pendidikan menengah. Kelas olahraga ini diharapkan dapat meningkatkan minat dan menyalurkan bakat siswa untuk menjadi atlet potensial dimasa yang akan datang. Kegiatan kelas olahraga di tingkat SMP ini adalah suatu kegiatan sebagai wadah pengembangan potensi siswa dalam bidang olahraga. Di Kota Bengkulu terdapat tiga sekolah yang memiliki kelas olahraga yaitu, SMP Negeri 16 Kota Bengkulu, SMP Negeri 18 Kota Bengkulu, dan SMP Negeri 2 Kota Bengkulu namun terdapat keterbatasan pihak sekolah dalam pengelolaan, fasilitas, kurangnya pengembangan program dan masih sedikit masyarakat yang memahami mengenai kelas olahraga.

Rumusan dalam penelitian ini adalah bagaimanakah implementasi kebijakan kelas olahraga di SMP Negeri Kota Bengkulu. Adapun tujuan dari untuk mengungkap permasalahan implementasi kebijakan kelas olahraga Sekolah
Menengah Pertama Negeri di Kota Bengkulu.

METODE

Dalam penelitian ini menggunakan jenis penelitian descriptive analitic dimana tidak berupaya mencari untuk pengujian hipotesis yang diturunkan dari teori. Peneliti berangkat kelapangan untuk mengumpulkan berbagai bukti melalui penelaahan terhadap fenomena dan berdasarkan hasil penelaahan, peneliti kemudian merumuskan teori. Penelitian dilakukan di wilayah pendidikan kota Bengkulu pada Sekolah Menengah Pertama Negeri yang memiliki kelas olahraga yaitu SMP Negeri 2 Kota Bengkulu, SMP Negeri 18 Kota Bengkulu dan SMP Negeri 16 Kota Bengkulu. dengan waktu penelitian dari tanggal 17 Januari - 1 Maret 2018. Pengambilan subjek dalam peneliian ini menggunakan teknik purposive, yaitu dengan memilih orang-orang yang dianggap tahu dengan fokus masalah seperti pihak yang terkait dengan pengambilan keputusan seperti kepala sekolah, guru, pelatih, pengurus dan siswa kelas olahraga.Penelitian ini mengambil objek penelitian seluruh yang berhubungan dengan adanya kelas olahraga pada Sekolah Menengah Pertama Negeri di Kota Bengkulu.

Dalam penelitian kualitatif, pengumpulan data dilakukan pada natural setting (kondisi yang alamiah), sumber data primer, dan teknik pengumpulan data lebih banyak pada observasi berperan serta (participan observation), wawancara mendalam (in depth interiew) dan dokumentasi. 
Penelitian ini menggunakan metode descriptive analitic yaitu kualitatif non statistik, pengumpulan data dengan cara meringkas data (reduction), kemudian disajikan secara sederhana (resentation) dalam bentuk tabel atau gambar dan terakhir penarikan kesimpulan(conclution)

\section{HASIL DAN PEMBAHASAN}

Kebijakan kelas olahraga

Penelitian ini dilaksanakan di Sekolah Menengah Pertama Negeri Kota Bengkulu.Kebijakan Kelas Olahraga di SMP Negeri Kota Bengkulu sudah ada sejak tahun 2010, tetapi secara resmi ditetapkan pada tahun 2014 berdasarkan Surat Keputusan dari walikota Bengkulu Nomor 2463/C3/KP/2014 tentang sekolah penyelenggara program kelas olahraga dan terlampir terdapat 83 Sekolah Menengah Pertama Negeri (SMP) yang menyelenggarakan kelas olahraga di Indonesia termasuk 2 sekolah di provinsi Bengkulu yaitu SMP Negeri 2 dan SMP Negeri 18 Kota Bengkulu.

"Kebijakan kelas olahraga di SMP Negeri 16 kota Bengkulu belum dimandatkan secara resmi, tetapi telah di undang dan terpilih mewakili provinsi Bengkulu pada seminar penyelenggaraan kelas olahraga di Jakarta pada tahun 2016, selepas dari seminar tersebut memiliki amanah untuk menyelenggarakan kelas olahraga dalam pengembangannya mendapatkan bantuan dana dari pemerintah". (Bapak Rio Lebrian selaku koordinator kelas olahraga)

\section{Hasil}

Implementasi Kebijakan Kelas Olahraga di SMP Negeri Kota Bengkulu

Berdasarkan hasil observasi dan wawancarajam pelajaran olahraga dan jam pelajaran umum ternyata tidak ada perbedaan dengan kelas reguler, tetap mengikuti kurikulum yang berlaku disekolah, yang membedakan justru kegiatan selepas dari jam sekolah bahwa siswa kelas olahraga wajib mengikuti jadwal latihan sesuai cabang olahraga mereka masing-masing dan selalu dipantau sebulan sekali oleh pihak pengurus kelas olahraga untuk tercapainya tujuan dari adanya kelas olahraga tersebut.

Penerimaan Siswa Kelas Olahraga

"kelas olahraga memiliki program latihan tersendiri, untuk itu sistem penerimaan peserta didik baru (PPDB) berbeda dengan kelas reguler, mereka harus melewati beberapa tes fisik dan kecabangan olahraga, hal ini bertujuan untuk menjaring para siswa yang memang berbakat dibidang olahraga ".(Hj.Karlina, koordinator kelas olahraga SMP Negeri 2 Kota Bengkulu).

"cabang olahraga yang ada di kelas olahraga itu berdasarkan hasil dari prestasi olahraga, dipilih mana yang lebih berpotensi dan kemudian dikembangkan"(Bapak Jimmy Ardiansya selaku koordinator kelas olahraga SMP Negeri 18 Kota Bengkulu)

"siswa kelas olahraga tiap tahunnya diterima sebanyak 32 orang/1 rombel"(Drs. Subhan Suwito selaku kepala sekolah SMP Negeri 18 Kota Bengkulu)

Berdasarkan hasil wawancara diismpulkan bahwa seluruh tes dilaksanakan disekolah dan dilapngan masing-masing sekolah yang memiliki kelas olahraga.

Pengelolaan Kelas Olahraga di SMP Negeri Kota Bengkulu

"pengurus kelas olahraga adalah tenaga kerja baik itu guru maupun staff 
yang ada disekolah, tetapi untuk pelatih banyak dari luar sekolah"(Rio Lebrian) Berdasarkan hasil penelitian Pengurus kelas olahraga di SMP Negeri Kota Bengkulu adalah guru olahraga disekolah tersebut dan tenaga kerja guru maupun staff Tata Usaha di sekolah tersebut terutama guru olahraga. Struktur kepengurusan terdiri dari Penanggung Jawab, ketua, Sekretaris, bendahara dan anggota yang maksimal terdiri dari 3 orang.

"pelatih untuk kelas olahraga diusahakan guru yang mengajar disekolah jika tidak ada, sekolah merekrut pelatih dari luar sekolah tentu saja yang memiliki sertifikat pelatih "(Sally, S.Pd selaku sekretaris sekaligus wali kelas olahraga di SMP Negeri 16 Kota Bengkulu)

"fasilitas olahraga di SMP Negeri 2 Kota Bengkulu masih tergolong minim, seperti halnya bola voli ada kisaran 7 bola tetapi yang masih layak pakai hanya 3 bola "(Bapak Suratno, S.Pd selaku guru olahraga di SMP Negeri Kota Bengkulu). Berdasarkan hasil observasi, wawancara dan dokumentasi mengenai fasilitas olahraga selain menggunakan fasilitas yang ada disekolah pelatih juga menggunakan fasilitas diluar sekolah seperti GOR, kolam renang dan stadion. Fasilitas olahraga di SMP Negeri Kota Bengkulu dinilai cukup tetapi masih kurang memadai, sehingga guru maupun pelatih harus pandai dan kreatif dalam penggunaannya,ditampilkan secara sederhana berikut jumlh fasilitas yang ada.

\begin{tabular}{c|l|c|c|c} 
No & $\begin{array}{l}\text { Fasilitas } \\
\text { olahraga }\end{array}$ & $\begin{array}{c}\text { SMPN } \\
\mathbf{2}\end{array}$ & $\begin{array}{c}\text { SMPN } \\
\mathbf{1 8}\end{array}$ & $\begin{array}{c}\text { SMPN } \\
\mathbf{1 6}\end{array}$ \\
\hline 1 & $\begin{array}{l}\text { Lapangan } \\
\text { basket }\end{array}$ & 1 & 1 & 1 \\
\hline 2 & $\begin{array}{l}\text { Lapangan } \\
\text { futsal }\end{array}$ & 1 & 1 & 1 \\
\hline 3 & $\begin{array}{l}\text { Lapangan } \\
\text { voli }\end{array}$ & 1 & 1 & 1 \\
\hline
\end{tabular}

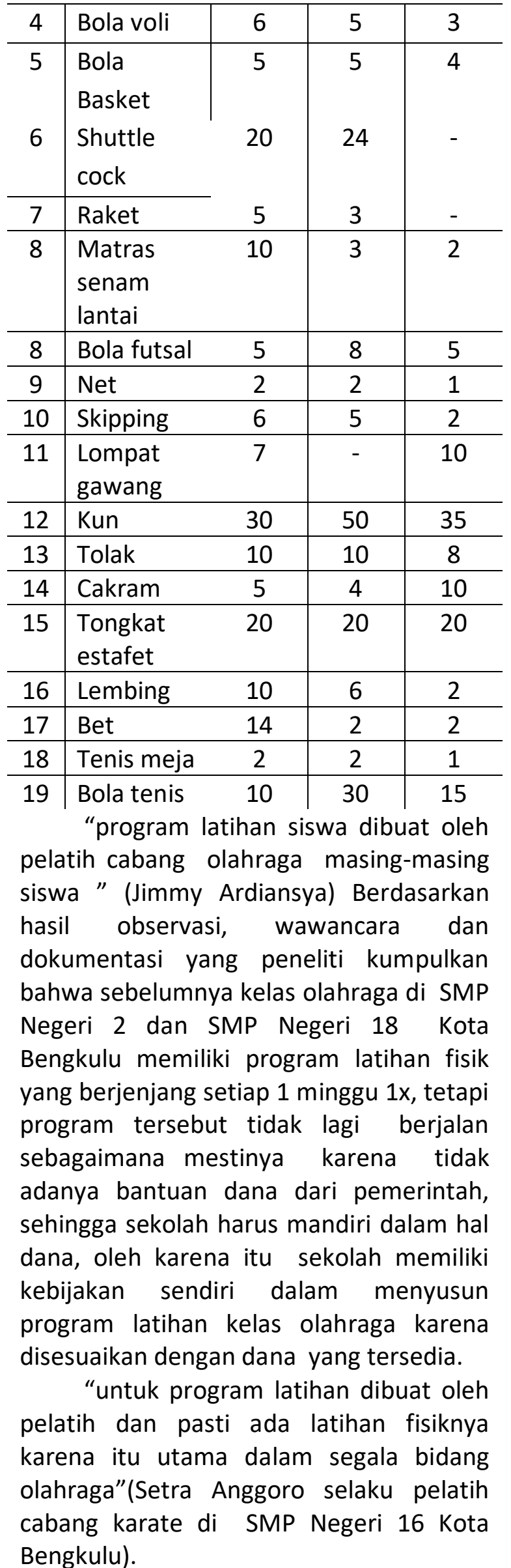


Dari data hasil penelitian mengenai program latihan kecabangan olahraga dipersiapkan oleh masing-masing pelatih dan selalu ada khusus untuk latihan kondisi fisik. Ada beberapa Pelatih yang hanya memberi tambahan interval waktu latihan namun ada juga pelatih yang memberi jadwal latihan tambahan diluar jadwal latihan kelas olahraga untuk persiapan mengikuti kejuaraan.

\section{Pendanaan}

"Kelas olahraga di SMP Negeri 18 Kota Bengkulu dari tahun 2010-2013 mendapatkan dana bantuan dari pemerintah untuk seluruh kegiatan olahraga mulai dari saat tes penerimaan siswa kelas olahraga, peralatan olahraga,honor pelatih dan lainlain"(Jimmy Ardiansya).

"kelas olahraga di SMP Negeri 2 Kota Bengkulu ini mendapat bantuan langsung dari Jakarta dari APBN selama 2 tahun dan dari APBD selama 2 tahun kemudian untuk selanjutnya sekolah secara mandiri hingga saat ini menghandalkan biaya dari uang komite"(Hj.Karlina)

Berdasarkan hasil observasi dan wawancara dana untuk kelas olahraga saat ini secara mandiri (sekolah itu sendiri) di SMP Negeri 2 Kota Bengkulu dengan kebijakan berdasarkan musyawarah diambil dari uang komite, sedangkan SMP 18 kota Bengkulu mengandalkan dana yang ada dari BOS (Bantuan Operasional Sekolah) dan yang masih mendapatkan bantuan dari APBN melalui dana block grant adalah SMP Negeri 16 Kota Bengkulu.

Faktor Penghambat dan Pendukung Implementasi Kebijakan Kelas Olahraga

Berdasarkan hasil observasi, wawancara dan dokumentasi mengenai beberapa faktor penghambat dan faktor pendukung implementasi kelas olahraga di SMP Negeri Kota Bengkulu ternyata hampir sama yaitu pada pendanaan dan fasilitas olahraga, dimana keduanya sangat berpengaruh demi kelancaran program kelas olahraga, dana dibutuhkan untuk kegiatan kelas olahraga apabila ada cabang olahraga yang mengikuti lomba, baik itu ditingkat kabupaten maupun provinsi, membutuhkan dana pendaftaran, konsumsi ataupun transport, begitupun dengan fasilitas dengan siswa yang banyak tetapi peralatan yang sedikit membuat pelaksanaan program latihan menjadi tidak efektif, sehingga guru harus sekreatif mungkin dalam melatih.

Prestasi

"ada bedanya sebelum ada kelas olahraga dan setelah diselenggarkan, terjadi peningkatan prestasi dibidang olahraga dan setiap ada event olahraga, biasanya selalu diwakili oleh anak kelas olahraga yang setidaknya masuk 3 besar, karena kadanag anak kelas olahraga ini kalah sama siswa yang latihan di PPLP karena memang porsi latihan mereka berbeda"(koordinator masing-masing sekolah kelas olahrga di SMP Negeri kota Bengkulu)

Berdasarkan hasil penelitian yang telah dilakukan melalui observasi, wawancara dan dokumentasi di SMP Negeri Kota Bengkulu yang memiliki kelas olahraga telah mencapai peningkatan prestasi yang cukup baik semenjak adanya kelas olahraga di SMP Negeri Kota Bengkulu, bahkan mencapai tingkat Nasional hal ini tidak lepas dari peran pelatih dan pengurus kelas olahraga.

\section{Simpulan}

Kelas olahraga di SMP Negeri Kota Bengkulu telah dimandatkan secara 
langsung oleh pemerintah melalui seminar penyelenggaraan kelas olahraga pada tahun 2010 di Jakarta yaitu untuk SMP Negeri 2 Kota Bengkulu dan SMP Negeri 18 Kota Bengkulu, secara resmi surat keputusan Direktur Pembinaan Sekolah Menengah Pertama Negeri, Direktorat Jenderal Pendidikan Dasar, Kementerian Pendidikan dan Kebudayaan Republik Indonesia, Nomor 2463/C3/KP/2014 Tentang Sekolah Penyelenggara Program Kelas Olahraga Tahun 2014 telah ditetapkan sebanyak 83 Sekolah Menengah Pertama Negeri di Indonesia termasuk SMP Negeri 2 Kota Bengkulu dan SMP Negeri 18 Kota Bengkulu. Kebijakan kelas olahraga di SMP Negeri 16 Kota Bengkulu secara langsung pada tahun 2016 melalui undangan seminar penyelenggaraan kelas olahraga di Jakarta dan langsung mendapatkan dana untuk membuka kelas olahraga.

Ditinjau secara umum perbedaan kelas olahraga di SMP Negeri Kota Bengkulu terletak pada pendanaan yang dari sumber dana anggaran untuk kelas olahraga berbeda setiap sekolah, program latihan percabang yang ditentukan oleh pelatih masing-masing yang berbeda, jumlah fasilitas olahraga yang berbeda karena sesuai dengan dana yang ada dari masing-masing sekolah, persamaan kelas olahraga secara umum dalam hal perekrutan siswa, pelatih dan cabang olahraga untuk siswa kelas olahraga disekolah. Implementasi Kebijakan kelas olahraga di SMP Negeri Kota Bengkulu dikatakan belum ideal atau belum berjalan sebagaimana mestinya karena masih banyak hal yang tidak sesuai dengan panduan pelaksanaan kelas olahraga dan dikhawatirkan akan menghambat tujuan awal adanya kelas olahraga.

\section{DAFTAR PUSTAKA}

Abidin.(2006). Kebijakan Pemerintahan. Jakarta: Rineka Cipta

Agustina.(2006). Konsep Kebijakan Publik Substantif dan Prosedural. Jakarta: PT RajaGrafindo Persada

Ahmadi, Ruslam.(2014). Metodologi Penelitian Kualitatif. Yogyakarta:Ar-ruzz Media

Alfiriani.(2016). Implementasi Kebijakan Kelas Olahraga di SMA Negeri 1 Sewon. S1 Skripsi. Fakultas IImu Pendidikan UNY

B.Suryosubroto.(2004). Manajemen Pendidikan di Sekolah Dasar dan Menengah. Jakarta: Rineka Cipta

Dian Pujianto dan Bayu Insanistyo.(2017). Dasar-dasar Penelitian Pendidikan Jasmani. FKIP Universitas Bengkulu Dimyati dan Mudjiono. (2013). Belajar dan Pembelajaran. Jakarta : Rineka Cipta

Greston.(2002). Kebijakan Sosial Sebagai Kebijakan Publik Dan Implementasinya

Bandung:Alfabeta.

Harsuki.(2012). Pengantar Manajemen Olahraga. Jakarta: PT RajaGrafindo Persada

Kompri.(2014). Manajemen Sekolah. Bandung:Alfabeta

Pitaloka, Septi Rizki.(2017). Implementasi Pembinaan Klub Bola Voli Usia Dini Di Sekolah Dasar Kota Bengkulu. S1 Skripsi. Fakultas IImu Pendidikan

Sudjana, Nana.(2005). Dasar-Dasar Proses Belajar Mengajar. Bandung : Sinar Baru Algesindo

Sugiyono.(2016). Memahami Penelitian Kualitatif. Bandung:Alfabeta

Syafaruddin (2008). Efektivitas Kebijakan Pendidikan. Jakarta: Rineka Cipta. 
Tangkudung, James. (2012). Kepelatihan

Olahraga Pembinaan Prestasi

Olahraga. Jakarta: Cerdas jaya

,(2016).Macam-macam

Metodologi Penelitian. Jakarta:

Lensa Media Pustaka Indonesia 